\title{
CORRIGENDUM
}

\section{Review of Carmela Murdocca's To Right Historical Wrongs: Race, Gender, and Sentencing in Canada. Vancouver: UBC Press, 2013. 280pp. - CORRIGENDUM}

Gillian Balfour

doi:10.1017/cls.2014.19. Published online by Cambridge University Press, 23 September 2014.

In the version of the book review by Gillian Balfour published on FirstView, ${ }^{1}$ the book author's name was incorrect. The author's name is Carmela Murdocca (not Carmella Murdocca). The book reviewer, editorial team, and publisher apologize to the author and readers for this error. The book review has been corrected to rectify this error.

\section{REFERENCE}

1. Gillian Balfour, "Review of Carmela Murdocca’s To Right Historical Wrongs: Race, Gender, and Sentencing in Canada," Canadian Journal of Law and Society / Revue Canadienne Droit et Société, 2014. doi:10.1017/cls.2014.19. 